\title{
LARGE expression in different types of muscular dystrophies other than dystroglycanopathy
}

\author{
Burcu Balci-Hayta ${ }^{1 *}$, Beril Talim², Gulsev Kale ${ }^{2}$ and Pervin Dincer ${ }^{1}$
}

\begin{abstract}
Background: Alpha-dystroglycan ( $\mathrm{aDG}$ ) is an extracellular peripheral glycoprotein that acts as a receptor for both extracellular matrix proteins containing laminin globular domains and certain arenaviruses. An important enzyme, known as Like-acetylglucosaminyltransferase (LARGE), has been shown to transfer repeating units of -glucuronic acid- $\beta 1,3-x y l o s e-\alpha 1,3-$ (matriglycan) to aDG that is required for functional receptor as an extracellular matrix protein scaffold. The reduction in the amount of LARGE-dependent matriglycan result in heterogeneous forms of dystroglycanopathy that is associated with hypoglycosylation of aDG and a consequent lack of ligand-binding activity. Our aim was to investigate whether LARGE expression showed correlation with glycosylation of aDG and histopathological parameters in different types of muscular dystrophies, except for dystroglycanopathies.

Methods: The expression level of LARGE and glycosylation status of aDG were examined in skeletal muscle biopsies from 26 patients with various forms of muscular dystrophy [Duchenne muscular dystrophy (DMD), Becker muscular dystrophy (BMD), sarcoglycanopathy, dysferlinopathy, calpainopathy, and merosin and collagen VI deficient congenital muscular dystrophies (CMDs)] and correlation of results with different histopathological features was investigated.
\end{abstract}

Results: Despite the fact that these diseases are not caused by defects of glycosyltransferases, decreased expression of LARGE was detected in many patient samples, partly correlating with the type of muscular dystrophy. Although immunolabelling of fully glycosylated aDG with VIA4-1 was reduced in dystrophinopathy patients, no significant relationship between reduction of LARGE expression and aDG hypoglycosylation was detected. Also, Merosin deficient CMD patients showed normal immunostaining with aDG despite severe reduction of LARGE expression.

Conclusions: Our data shows that it is not always possible to correlate $L A R G E$ expression and aDG glycosylation in different types of muscular dystrophies and suggests that there might be differences in aDG processing by LARGE which could be regulated under different pathological conditions.

Keywords: LARGE, Alpha-dystroglycan, Hypoglycosylation, Muscular dystrophy, Skeletal muscle

\section{Background}

Dystroglycan (DG), a heterodimeric transmembrane glycoprotein, is a central component of the dystrophinglycoprotein complex (DGC) and responsible for a variety of physiological and developmental processes, including muscle stabilization, basement membrane assembly, cell migration and signalling [1]. The protein is

\footnotetext{
* Correspondence: burcub@hacettepe.edu.tr

'Department of Medical Biology, Hacettepe University Faculty of Medicine, 06100 Sihhiye, Ankara, Turkey

Full list of author information is available at the end of the article
}

synthesized as a precursor molecule that is post-translationally cleaved into a cell surface $\alpha$ - and a transmembrane $\beta$ subunits [2]. The extracellular subunit, alpha-dystroglycan $(\alpha D G)$, is a highly glycosylated basement membrane protein that acts as a receptor for non-collagenous proteins in the extracellular matrix (ECM) containing laminin globular domains, and for Old World arenaviruses [1, 3-5]. Mutations in the DG-encoding gene (DAG1) [6,7] and several other genes whose products are involved, directly or indirectly, in glycosylation pathway of $\alpha \mathrm{DG}$ [8] have been identified in

(C) The Author(s). 2018 Open Access This article is distributed under the terms of the Creative Commons Attribution 4.0 International License (http://creativecommons.org/licenses/by/4.0/), which permits unrestricted use, distribution, and 
various forms of congenital and limb-girdle muscular dystrophies (CMD/ LGMDs). These disorders are all associated with hypoglycosylation of $\alpha \mathrm{DG}$ and a consequent lack of ligand-binding activity and thus are collectively termed as dystroglycanopathies [9].

Although the precise glycosylation pathway of $\alpha \mathrm{DG}$ is not fully understood, the function of Like-acetylglucosaminyltransferase (LARGE) enzyme has been of particular interest. It is encoded by one of the largest genes (LARGE) in the human genome [10-12], which is mutated in the myodystrophy mouse (LARGE-myd) [10, 13] and in patients affected by MDC1D, a subclass of CMD associated with skeletal muscle and structural brain involvement [11]. The mentioned enzyme is a bifunctional glycosyltransferase, with both xylosyltransferase and glucuronyltransferase activities and plays an important role in the glycosylation pathway of $\alpha D G$. It transfers a novel heteropolysaccharide structure, repeating units of -glucuronic acid- $\beta 1,3$-xylose- $\alpha 1,3$ - to the basement membrane receptor DG [14]. This structure has been recently termed as matriglycan, which is bound to the $\alpha \mathrm{DG}$ through a phosphorylated $\mathrm{O}$-mannosyl glycan anchored at Thr317 and Thr319 in the mucin-like domain $[8,15,16]$. It is required for the $\alpha \mathrm{DG}$ to bind laminin-G domaincontaining ECM ligands including laminin, agrin, perlecan and neurexin $[4,17-19]$. It has been reported that LARGE-dependent matriglycan structure plays an important role for normal skeletal muscle function and the consequent reduction in the amount of glycans on $\alpha D G$ causes structural alterations of the basement membrane, immature neuromuscular junctions and dysfunctional muscle predisposed to dystrophy [20]. Uniquely, transient overexpression of $L A R G E$ has been shown to increase glycosylation of $\alpha D G$ as evaluated by increased immunoreactivity to antibodies IIH6 and VIA4-1 both of which are known to recognize carbohydrate moieties and leads to a recovery of receptor function in cells derived from patients diagnosed as Fukuyama CMD (FCMD), muscle-eye-brain disease (MEB) and Walker-Warburg syndrome (WWS) [17]. Also, the identical results has been reported in vivo, after adenovirus or adeno-associated virus mediated gene transfer of LARGE in Fukutin (FKTN), Fukutin-related protein (FKRP) and Protein-O-mannose $\beta 2-N$-acetylglucosaminyltransferase 1 (POMGNT1) deficient mice models [21-23]. Although a recent study demonstrates that fukutin is required for the ability of LARGE to hyperglycosylate $\alpha \mathrm{DG}$ [24], this strategy is already regarded as a promising therapeutic approach for preventing/slowing progression of a broad range of dystroglycanopathies regardless of the causative gene defects. However, it remains crucial to analyze such a strategy in different types of muscular dystrophies other than dystroglycanopathy.

In this study, we analyzed the influence of $L A R G E$ gene expression profile on VIA4-1 immunoreactivity in different types of muscular dystrophies, except for dystroglycanopathies [i.e. Duchenne muscular dystrophy (DMD), Becker muscular dystrophy (BMD), sarcoglycanopathy, dysferlinopathy, calpainopathy, and merosin and collagen VI deficient CMDs]. Correlation between different histopathological features, LARGE expression profile and glycosylation status of $\alpha D G$ was investigated. We detected reduced expression level of LARGE in different types of muscular dystrophies, partly correlating with the severity of dystrophic changes, but we did not find any significant relationship between reduction of LARGE expression and VIA4-1 immunoreactivity.

\section{Methods}

\section{Patients and muscle biopsies}

The study protocol was approved by the Hacettepe University Faculty of Medicine Ethical Review Board (FON 10/35-11). As the legal age of consent is 18 years of age in Turkey, written informed consent was obtained from patients' parents or legal guardians at the time of diagnostic muscle biopsy. Skeletal muscle biopsies from 3 controls and 26 patients with clinicopathological and/ or molecular diagnosis of various forms of muscular dystrophy other than dystroglycanopathy were included in this study. The number of patients in each disease type is indicated in parentheses; DMD (3), BMD (4), sarcoglycanopathy (5), dysferlinopathy (1), calpainopathy (1), Merosin deficient CMD (4), Collagen VI deficient CMD (3), unclassified CMD (2), and unclassified MD (3). All patients have been investigated in the Department of Pediatrics at Hacettepe University Faculty of Medicine and open biopsies were taken from vastus lateralis muscle at the time of diagnosis. The muscle biopsy specimens were rapidly frozen in isopentane cooled in liquid nitrogen and kept at $-80^{\circ} \mathrm{C}$ until use. Serial transverse muscle sections were cut by cryostat for histochemical staining. Standard histological and histochemical techniques were applied to cryostat sections, including Haematoxylin and eosin (H\&E), modified Gomori trichrome, periodic acid Schiff, oil-red-O, nicotinamide adenine dinucleotide dehydrogenase-tetrazolium reductase, succinic dehydrogenase, cytochrome-c oxidase and ATPase. Immunohistochemical and/or immunofluorescent studies were done at the time of diagnosis, using antibodies against dystrophins, sarcoglycans, dysferlin, laminin $\alpha 2$ (merosin), collagen VI, and $\alpha \mathrm{DG}$, as appropriate.

\section{Histopathological evaluation}

H\&E stained archive sections were examined to identify the severity of various dystrophic changes, including necrosis, regeneration, adiposis, endomysial and perimysial fibrosis and inflammation. These pathological changes were scored from 0 (absent) to 4 (severe). 


\section{Immunofluorescent staining}

For immunofluorescent staining, skeletal muscle cryosections of $7 \mu \mathrm{m}$ were immunostained with primary antibodies $[1 / 10$ for mouse anti- $\alpha$-Dystroglycan antibody (clone VIA4-1 against fully glycosylated form of $\alpha \mathrm{DG}$, Millipore), $1 / 50$ for sheep anti- $\alpha$-Dystroglycan core antibody (R\&D Systems: AF6868), 1/100 for mouse anti-Spectrin (NCL-SPEC1 Clone: RBC2/3D5, Novocastra), 1:20 for anti-Beta-Dystroglycan (BDG) (NCL-b-DG Clone 43DAG1/8D5, Novocastra) and 1:1000 for mouse anti-laminin $\alpha 2$ (MAB1922 Chemicon (Millipore)] for 1 $\mathrm{h}$ at room temperature, followed by incubation with Alexa Fluor 488 goat anti-mouse or donkey anti-sheep IgG antibodies (Molecular Probes) at 1:1000 dilution for $45 \mathrm{~min}$ at room temperature. All dilutions and washing steps were made in phosphate buffered saline. Immunostained sections were then mounted and observed with epifluorescence using a Nicon Eclipse E400 microscope. The fluorescent labeling was scored from 0 (absent) to 3 (intense) using a scale based on the proportion of positive fibers and intensity relative to the control muscle sections.

\section{Quantitative real-time PCR (qRT-PCR)}

In order to assess the expression of LARGE, total RNA was extracted from liquid nitrogen fresh-frozen skeletal muscle tissues $\left(3 \mathrm{~mm}^{3}\right)$ from 26 patiens and 3 control samples using RNeasy fibrous tissue mini kit (Qiagen) and cDNA was synthesized from $500 \mathrm{ng}$ RNA using QuantiTect Reverse Transcription kit (Qiagen) according to manufacturer's guidelines. Real-time PCR was then performed using SYBR Green JumpStart TaqReadyMix kit (Sigma) on Rotor-Gene $6000^{\text {tix }}$ (Corbett Research) with the following conditions: $2 \mathrm{~min}$ at $94^{\circ} \mathrm{C}$, followed by 40 cycles of $5 \mathrm{~s}$ at $94^{\circ} \mathrm{C}, 10 \mathrm{~s}$ at $58^{\circ} \mathrm{C}$, and $15 \mathrm{~s}$ at $72{ }^{\circ} \mathrm{C}$. Reactions were performed in a total volume of $10 \mu \mathrm{L}$, including $5 \mu \mathrm{L}$ SYBR Green JumpStart TaqReadyMix kit (Sigma), $1.2 \mu \mathrm{l}$ of $25 \mathrm{mM} \mathrm{MgCl}_{2}$ (Sigma), $0.4 \mu \mathrm{l}$ each of $10 \mathrm{mM}$ forward and reverse primers and $1 \mu \mathrm{l}$ of template cDNA. Mastermix with no cDNA was used as the no template control whereas water was used as the negative control. The relative amount of mRNA, normalized to an internal control human beta-actin (ACTB) and relative to a calibrator (control), was calculated by $2^{-\Delta \Delta C T}$. Primers used were as follows: LARGE-F: 5'-TGAGCCGTATGTTGTTGTG AGAC-3'; LARGE-R: 5'-GATGCGGTATTGCTTGTTG GAAC-3' and ACTB-F: 5' - CGCAAAGACCTGTACGC CAAC -3'; ACTB-R: 5' - GAGCCGCCGATCCACACG $-3^{\prime}$. All reactions were performed in triplicate and optimal threshold in 95-100\% efficiency. All data was analyzed using Rotor-Gene 6000 Series Software 1.7 (Corbett Research).

\section{Statistical analysis}

All experiments performed at least three times and data were evaluated as means \pm SD. The significance of differences between experimental groups was determined using Mann-Whitney $\mathrm{U}$ test. $p$ values less than 0.05 were considered statistically significant.

\section{Results}

We assessed human muscle biopsies from DMD, BMD, sarcoglycanopathy, calpainopathy, dysferlinopathy, and merosin and collagen VI deficient CMDs, in addition to unclassified CMDs and MDs. Scoring for the severity of histopathological features and age at biopsy for each patient are shown in Table 1. In each muscular dystrophy group, samples had variable severity of histopathological findings such as necrosis, regeneration, fibrosis, adiposis and inflammation. Even some patients with the same diagnosis and similar age of biopsy showed different severity of pathological changes.

We first assessed the expression level of $L A R G E$ by qRT-PCR and detected reduced expression level of $L A R G E$ gene in analyzed samples, partly correlating with the form of muscular dystrophy (Fig. 1). The reduction of $L A R G E$ expression was more significant in all cases of DMD (P1, P2 and P3) and merosin deficient CMD (P14, P15, P16 and P17) as compared to control skeletal muscle. Also, LARGE mRNA levels were markedly reduced in all BMD cases, except one (P6). The expression of $L A R G E$ was similarly reduced in two cases of unclassified CMD (P22 and P23) and MD (P24 and P25), who had similar histopathological patterns. However, decreased expression in one case of Collagen VI deficient CMD (P18) with mild dystrophic features remains unexplained. The results of our study revealed different expression profiles for $L A R G E$ also among patients with different types of sarcoglycanopathies. Reduced $L A R G E$ expression levels were found also in the single dysferlinopathy (P13) and calpainopathy (P21) patients compared with age-matched healthy controls, with more severe reduction in $L A R G E$ and more severe dystrophic features in the case with dysferlin deficiency.

In order to reveal a correlation between LARGE expression and functional glycosylation of $\alpha \mathrm{DG}$, skeletal muscle sections were immunostained using VIA4-1 antibody against fully glycosylated form of $\alpha \mathrm{DG}$, and evaluated together with $\alpha \mathrm{DG}$ core protein (Fig. 2), beta-dystroglycan and laminin $\alpha 2$ immunostaining. The spectrum of VIA4-1 labeling was very variable and ranged from an absent to intense, compared with control skeletal muscle, whereas the immunoreactivity of core protein was indistinguishable between control and patients (Fig. 3). Therefore, the loss of VIA4-1 reactivity in some specimens reflects a reduction of $\alpha$-DG glycosylation, rather than loss of $\alpha-D G$ core protein expression. 
Table 1 The clinicopathological diagnosis and histopathological characteristics of the patients (Assessment scores: 0: absent; 1: rare; 2: mild; 3: moderate; 4: severe)

\begin{tabular}{|c|c|c|c|c|c|c|c|c|c|}
\hline$\#$ & Necrosis & Regeneration & $\begin{array}{c}\text { Endomysial } \\
\text { fibrosis }\end{array}$ & $\begin{array}{l}\text { Perimysial } \\
\text { fibrosis }\end{array}$ & Adiposis & Inflammation & Age & Ambulatory status & Diagnosis \\
\hline P1 & 1 & 2 & 4 & 4 & 4 & 2 & $8 \mathrm{yr}$ & Ambulant & \multirow{3}{*}{ DMD } \\
\hline P2 & 2 & 2 & 2 & 3 & 2 & 2 & $8 \mathrm{yr}$ & Ambulant & \\
\hline P3 & 4 & 3 & 2 & 2 & 2 & 4 & $6 \mathrm{yr}$ & Ambulant & \\
\hline P4 & 3 & 3 & 3 & 4 & 2 & 3 & $8 \mathrm{yr}$ & Ambulant & \multirow{4}{*}{ BMD } \\
\hline P5 & 3 & 3 & 2 & 2 & 2 & 2 & $7 \mathrm{yr}$ & Ambulant & \\
\hline P6 & 3 & 4 & 2 & 2 & 3 & 3 & $2 \mathrm{yr}$ & Ambulant & \\
\hline P7 & 1 & 3 & 3 & 4 & 4 & 2 & $10 \mathrm{yr}$ & Ambulant & \\
\hline P8 & 3 & 3 & 2 & 3 & 0 & 3 & $1 \mathrm{yr}$ & Ambulant & \multirow[t]{2}{*}{ Sarcoglycanopathy } \\
\hline P9 & 0 & 2 & 0 & $\mathbf{0}$ & 0 & 0 & $2,5 \mathrm{yr}$ & Ambulant & \\
\hline P10 & 3 & 3 & 0 & 0 & 2 & 3 & $6 \mathrm{yr}$ & Ambulant & \multirow{3}{*}{ g-Sarcoglycanopathy } \\
\hline P11 & 0 & 2 & 0 & 0 & 2 & 0 & $4 \mathrm{yr}$ & Ambulant & \\
\hline $\mathbf{P 1 2}$ & 0 & 3 & 1 & 0 & 0 & 1 & $8 \mathrm{yr}$ & Ambulant & \\
\hline P13 & 4 & 4 & 3 & 2 & 1 & 4 & $15 \mathrm{yr}$ & Ambulant & Dysferlinopathy \\
\hline P14 & 1 & 3 & 3 & 3 & 3 & 3 & $7 \mathrm{mo}$ & Non-ambulant (infant) & \multirow{4}{*}{ Merosin deficient CMD } \\
\hline P15 & 1 & 3 & 2 & 2 & 2 & 4 & $8 \mathrm{mo}$ & Non-ambulant (infant) & \\
\hline P16 & 1 & 1 & 2 & 3 & 4 & 2 & $3 \mathrm{yr}$ & Non-ambulant & \\
\hline P17 & 1 & 2 & 2 & 2 & 2 & 2 & $3 \mathrm{yr}$ & Non-ambulant & \\
\hline P18 & 1 & 2 & 2 & 2 & 3 & 1 & $5 \mathrm{yr}$ & Ambulant & \multirow{3}{*}{$\begin{array}{c}\text { Collagen VI deficient } \\
\text { CMD }\end{array}$} \\
\hline P19 & 0 & 1 & 2 & $\mathbf{0}$ & 0 & $\mathbf{0}$ & $3,5 \mathrm{yr}$ & Non-ambulant & \\
\hline P20 & 0 & 0 & 0 & 0 & 0 & 0 & $6 \mathrm{mo}$ & Non-ambulant (infant) & \\
\hline P21 & 2 & 3 & 3 & 2 & 0 & 3 & $13 \mathrm{yr}$ & Ambulant & Calpainopathy \\
\hline P22 & 2 & 3 & 3 & 2 & 3 & 3 & $10 \mathrm{yr}$ & Ambulant & \multirow[t]{2}{*}{ CMD, unclassified } \\
\hline P23 & 2 & 3 & 3 & 3 & 3 & 3 & $4 \mathrm{yr}$ & Ambulant & \\
\hline P24 & 0 & 2 & 2 & 0 & 2 & 1 & $12 \mathrm{yr}$ & Ambulant & \multirow{3}{*}{ MD, unclassified } \\
\hline P25 & 0 & 1 & 2 & $\mathbf{0}$ & 2 & 2 & $14 \mathrm{yr}$ & Ambulant & \\
\hline P26 & 2 & 3 & 2 & 0 & 0 & 3 & $9 \mathrm{yr}$ & Ambulant & \\
\hline Control-1 & $\mathbf{0}$ & $\mathbf{0}$ & 0 & $\mathbf{0}$ & 0 & 0 & $6 \mathrm{yr}$ & Ambulant & \multirow{3}{*}{---} \\
\hline Control-2 & 0 & 0 & 0 & $\mathbf{0}$ & $\mathbf{0}$ & 0 & $3 \mathrm{yr}$ & Ambulant & \\
\hline Control-3 & 0 & 0 & 0 & 0 & 0 & 0 & $17 \mathrm{yr}$ & Ambulant & \\
\hline
\end{tabular}

The skeletal muscle of patients with DMD showed a marked depletion of $\alpha$ DG glycosylation. The reduction of VIA4-1 labeling in BMD group ranged from an absence on most fibres to a very mild reduction. Also, in some patients with sarcoglycanopathy, Collagen VI deficient CMD and unclassified MD, a mild reduction of sarcolemmal labelling with VIA4-1 antibody was detected. Interestingly, patient 8 and 18 displayed an almost total absence of $\alpha \mathrm{DG}$ glycosylation relative to other patients within their group. Spectrin appeared normal in all cases indicating that the reduction in $\alpha D G$ hypoglycosylation was not due to non-specific damage of the plasma membrane. Except for merosin deficient CMDs, laminin $\alpha 2$ staining was also normal in all analyzed cases. Labeling of the transmembrane protein $\beta D G$ was preserved in most cases, although a mild reduction has been reported in 9 of the 26 cases, mostly in dystrophinopathies. There was no significant relationship between reduction of $L A R G E$ expression and $\alpha D G$ hypoglycosylation, most obvious example being the merosin deficient CMD patients (P14, P15, P16 and P17)
(Figs. 1 and 3) who showed normal immunostaining with $\alpha D G$ despite severe reduction of $L A R G E$ expression.

\section{Discussion}

In order to determine correlations between $L A R G E$ expression, glycosylation of $\alpha \mathrm{DG}$ and histopathological parameters, we analyzed $L A R G E$ gene expression profile and glycosylation status of $\alpha D G$ in various forms of muscular dystrophies, except for dystroglycanopathies. The expression level of LARGE was analyzed by qRT-PCR in skeletal muscle biopsies from 26 patients diagnosed as different forms of muscular dystrophy with various histopathological phenotypes (Table 1). Our findings indicated that most of the patients with severe histopathological phenotype (DMD and merosin deficient CMD) have decreased LARGE expression levels compared to control skeletal muscle (Fig. 1). We then evaluated whether there was a relationship between $L A R G E$ expression and $\alpha \mathrm{DG}$ glycosylation. The functional glycosylation of $\alpha \mathrm{DG}$ is associated with the 


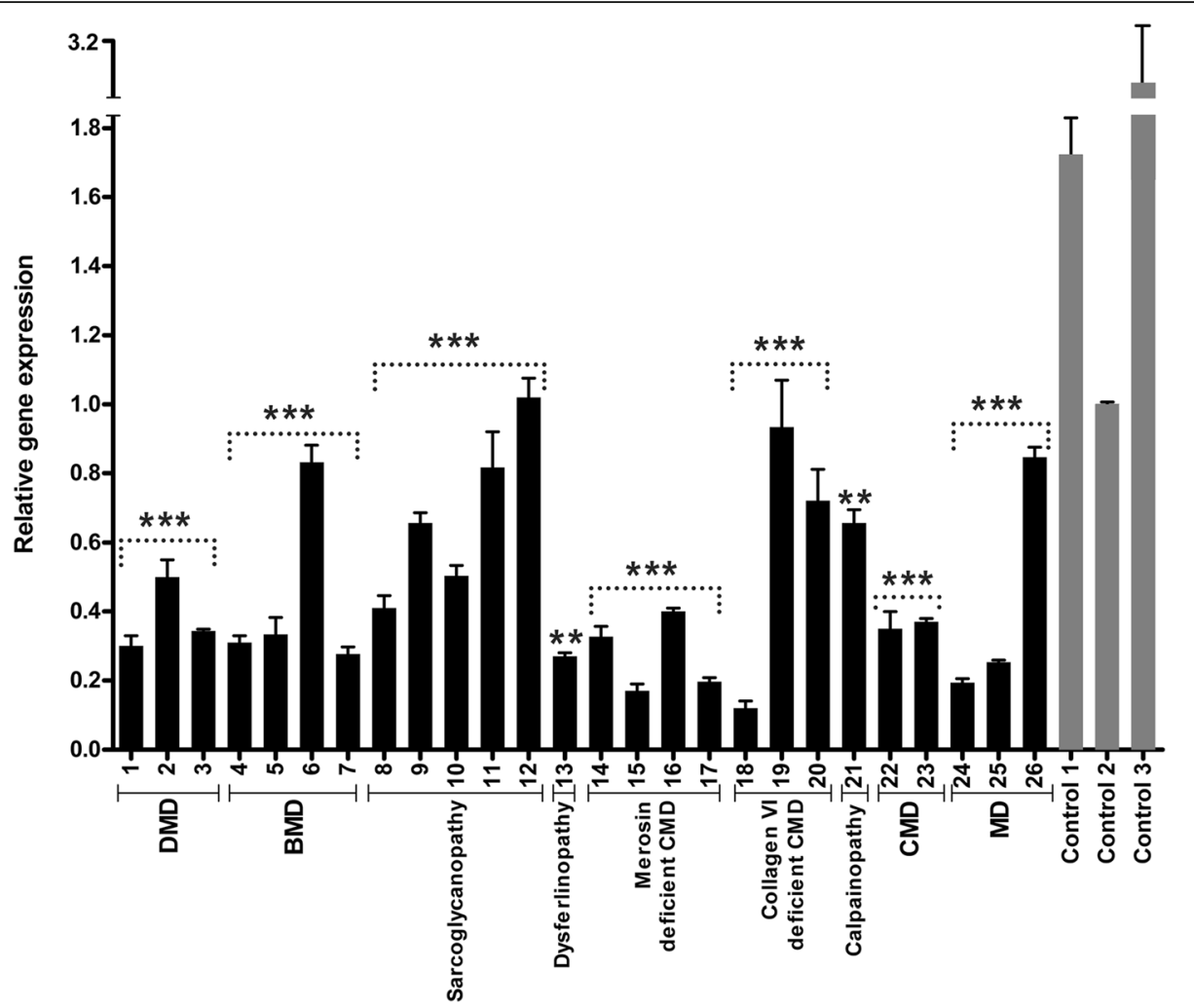

Fig. 1 Relative expression levels of LARGE, measured by quantitative real time PCR in different types of muscular dystrophies. Bar graph representations are shown of the mean \pm SEM values of the expression levels of patients (dark grey) and controls (light grey), respectively. Each bar represents the combined relative expression of three independent experiments measured by triplicate. Control 2 is used as calibrator. Error bars indicate standard deviations. Asterisks denote statistical significance as compared to the average of control group (Mann-Whitney $\mathrm{U}$ test, $\left.{ }^{* *} p<0.01,{ }^{* *} p<0.001\right)$

binding of either IIH6 and/or VIA4-1 antibodies to $\alpha$ DG. Thus, immunofluorescence staining was done using the widely used VIA4-1 antibody. Our findings indicate that irrespective of the muscular dystrophy type, the degree of hypoglycosylation varied (Figs. 2 and 3) and there was generally no correlation with clinical/histopathological severity. Similar results have previously been reported in dystroglycanopathy patients with Protein-O-mannosyl transferase 1 (POMT1), Protein-O-mannosyl transferase 2 (POMT2), POMGnT1, FKTN and FKRP mutations [25]. Also, our results were not consistent with the findings which suggests a correlation between a reduction in $\alpha$ DG labeling and the clinical severity in mild, late-onset LGMD type 2I and severe CMD $[20,26]$. On the other hand, we observed a severe reduction of $\alpha$ DG glycosylation in skeletal muscle biopsies of dystrophinopathy patients as a secondary finding, which has already been shown in DMD patients and $\mathrm{mdx}$ mouse [27, 28]. In contrast to those findings, the labelling obtained using the $\alpha \mathrm{DG}$ core antibody was preserved in all patients, which suggested that the glycosylation of $\alpha \mathrm{DG}$ is affected independently of DG protein expression.
In dystroglycanopathies, the effects of decreased glycosylation on laminin binding are variable $[4,11]$. Therefore, further studies are necessary to evaluate if hypoglycosylation of $\alpha D G$ affects laminin binding or other functions of $\alpha \mathrm{DG}$ in different types of muscular dystrophies other than dystroglycanopathy. Campbell and colleagues have previously demonstrated that short LARGE-glycan repeats reduces normal physiological function of muscle and predisposes it to dystrophy and showed that upregulation of $L A R G E$ and DG facilitates extension of LARGE-glycan repeat chains in differentiating mouse muscle [20]. However, consistent with our preliminary findings [29], we did not find any significant relationship between reduction of $L A R G E$ expression and $\alpha \mathrm{DG}$ hypoglycosylation (Figs. 1 and 3), except for DMD. Our results suggest that LARGE enzyme may have an additional function in skeletal muscle fibers that is probably distinct from adding a critical sugar chain onto $\alpha D G$. Equally likely is that the RNA changes in LARGE, while present, are not related at all to the MD phenotype. Transcriptional changes are difficult to interpret in prediction effects downstream. 

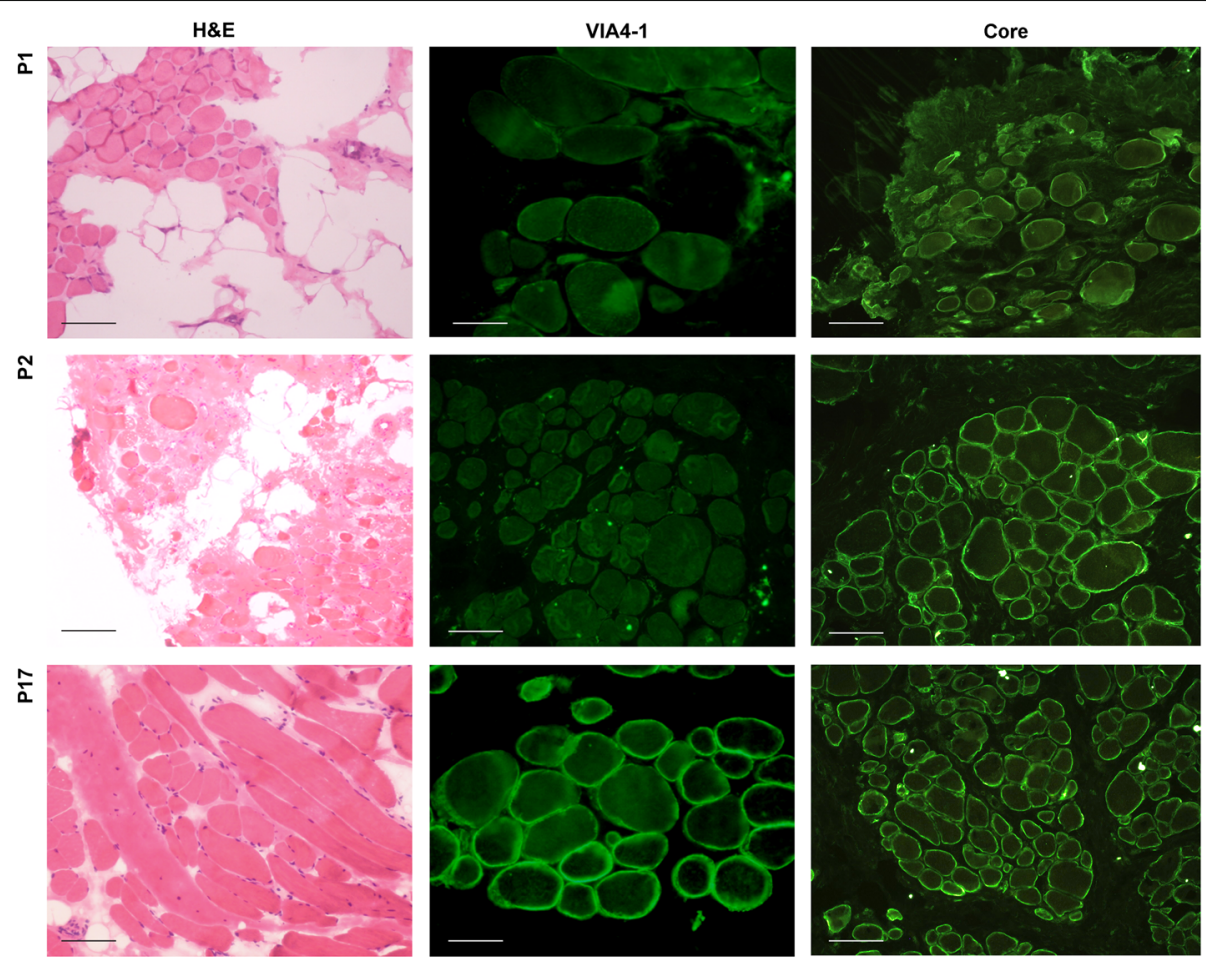

ָัญ
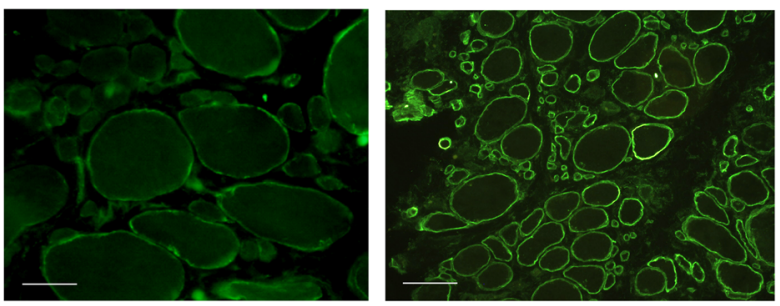

Fig. 2 Illustrative images of muscle sections with hematoxylin and eosin staining (left-hand panel; scale bars: $40 \mu m$.), glycosylated aDG labeling with VIA4-1 antibody (middle panel; scale bars: P1, P17 and P23: 20 mm.; P2: $40 \mu \mathrm{m}$.) and a-DG core antibody (right-hand panel; scale bars: $40 \mu \mathrm{m}$.). aDG labeling was normal in merosin deficiency (P17), mildly reduced in CMD (P23), but severely reduced/absent in cases with dystrophin deficiency (P1 and P2). Expression of the core aDG protein was well preserved in all samples

\begin{tabular}{|c|c|c|c|c|c|c|c|c|c|c|c|c|c|c|c|c|c|c|c|c|c|c|c|c|c|c|c|c|}
\hline \multirow[b]{2}{*}{ PATIENTS } & \multicolumn{3}{|c|}{ 号 } & \multicolumn{4}{|c|}{$\sum_{\text {m }}^{O}$} & \multicolumn{4}{|c|}{ 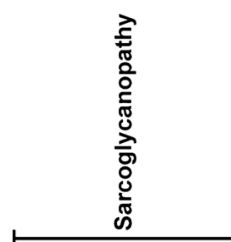 } & 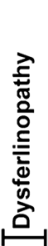 & \multicolumn{4}{|c|}{ 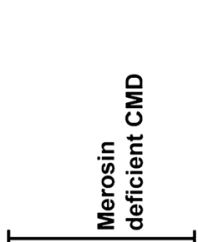 } & \multicolumn{3}{|c|}{ 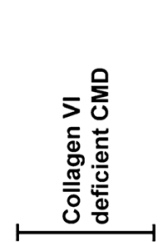 } & \multirow[t]{2}{*}{ 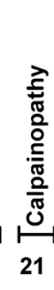 } & \multicolumn{2}{|c|}{ 沗 } & \multicolumn{3}{|c|}{ 号 } & \multirow[b]{2}{*}{$C-1$} & \multirow[b]{2}{*}{ C-2 } & \multirow[b]{2}{*}{$C-3$} \\
\hline & 1 & 2 & 3 & 4 & 5 & 6 & 7 & 8 & $9 \quad 1$ & $\begin{array}{ll}0 & 11\end{array}$ & 12 & 13 & 14 & 15 & 16 & 17 & 18 & 19 & 20 & & 22 & 23 & 24 & 25 & 26 & & & \\
\hline VIA4-1 & 1 & 0 & 0 & 0 & 12 & 2 & 2 & 0 & 3 & 3 & 2 & 3 & 3 & 3 & 3 & 3 & 0 & 2 & 3 & 3 & 2 & 2 & 3 & 2 & 3 & 3 & 3 & 3 \\
\hline$\beta D G$ & 3 & 2 & 2 & 2 & 2 & 2 & 3 & 2 & 3 & 3 & 3 & 3 & 3 & 3 & 3 & 3 & 2 & 3 & 2 & 3 & 3 & 3 & 3 & 3 & 2 & 3 & 3 & 3 \\
\hline Laminin $\alpha 2$ & 3 & 3 & 3 & 3 & 3 & 3 & 3 & 33 & 33 & 3 & 3 & 3 & 0 & 0 & 0 & 0 & 3 & 3 & 3 & 3 & 3 & 3 & 3 & 3 & 3 & 3 & 3 & 3 \\
\hline Spectrin & 3 & 3 & 3 & 3 & 3 & 3 & 3 & 33 & 33 & 3 & 3 & 3 & 3 & 3 & 3 & 3 & 3 & 3 & 3 & 3 & 3 & 3 & 3 & 3 & 3 & 3 & 3 & 3 \\
\hline Core & 3 & 3 & 3 & 3 & 3 & 3 & 3 & 3 & 3 & 3 & 3 & 3 & 3 & 3 & 3 & 3 & 3 & 3 & 3 & 3 & 3 & 3 & 3 & 3 & 3 & 3 & 3 & 3 \\
\hline
\end{tabular}

Fig. 3 Representative results of immunofluorescence staining with VIA4-1, $\beta D G$, Laminin, Spectrin and aDG core antibodies. Immunolabeling scores were assigned to a scale of 0 to $3:(0=$ absent; 1 = faint staining; $2=$ moderate staining; $3=$ intense staining $)$ 


\section{Conclusions}

Glycosylation of $\alpha \mathrm{DG}$ undergoes tissue and developmental stage specific changes, which indicates that it may have different roles in developing and fully differentiated skeletal muscle $[4,30]$. $\alpha$ DG glycosylation is likely to be regulated by developmental and differential expression of numerous enzymes, including LARGE. Therefore the detected $L A R G E$ expression profiles in various form of muscular dystrophies may still reflect responses to pathological processes of skeletal muscle related to $\alpha D G$ glycosylation. Our cohort encompassed a wide range of muscular dystrophies, suggesting that a different pathomechanism may explain the relationship between $L A R G E$ expression and $\alpha \mathrm{DG}$ glycosylation in the pathogenesis of different types of muscular dystrophies and highlighting the need for further studies.

\begin{abstract}
Abbreviations
ACTB: Beta-actin; BMD: Becker muscular dystrophy; CMD: Congenital muscular dystrophy; DAG1: DG-encoding gene; DG: Dystroglycan; DGC: Dystrophin-glycoprotein complex; DMD: Duchenne muscular dystrophy; ECM: Extracellular matrix; FCMD: Fukuyama congenital muscular dystrophy; FKRP: Fukutin-related protein; FKTN: Fukutin; H\&E: Haematoxylin and eosin; LARGE: Like-acetylglucosaminyltransferase; LARGEmyd: myodystrophy mouse; LGMD: Limb-girdle muscular dystrophy; MEB: Muscle-eye-brain disease; POMGNT1: Protein-O-mannose B2-Nacetylglucosaminyltransferase 1; POMT1: Protein-O-mannosyl transferase 1; POMT2: Protein-O-mannosyl transferase 2; qRT-PCR: Quantitative real-time PCR; WWS: Walker-Warburg syndrome; aDG: Alpha-dystroglycan
\end{abstract}

\section{Acknowledgements}

Not applicable.

\section{Funding}

This study was supported by a grant from Hacettepe University Scientific Research Projects Coordination Unit (grant number 011 D01 101 003).

\section{Availability of data and materials}

The datasets analyzed and/or generated during the current study are available from the corresponding author on reasonable request.

\section{Authors' contributions \\ $\mathrm{BBH}$ drafted the manuscript, obtained funding for this study, designed and performed the experiments. BT provided biopsy specimens, evaluated the histopathological data and revised the manuscript. PD contributed to the design and implementation of the study. GK contributed to the evaluation of the histopathological data and made a significant intellectual contribution to this study. All authors discussed the results and contributed to the final manuscript.}

\section{Ethics approval and consent to participate}

This study was performed with the approval of the Ethical Review Board of Hacettepe University Faculty of Medicine, Ankara, Turkey (FON 10/35-11). As the legal age of consent is 18 years of age in Turkey, written informed consent was obtained from patients' parents or legal guardians at the time of diagnostic muscle biopsy. All studies were conducted in accordance with the principles of the Declaration of Helsinki.

\section{Consent for publication}

Not applicable.

\section{Competing interests}

The authors declare that they have no competing interests.

\section{Publisher's Note}

Springer Nature remains neutral with regard to jurisdictional claims in published maps and institutional affiliations.

\section{Author details}

${ }^{1}$ Department of Medical Biology, Hacettepe University Faculty of Medicine, 06100 Sihhiye, Ankara, Turkey. ${ }^{2}$ Department of Pediatrics, Pathology Unit, Hacettepe University Faculty of Medicine, 06100 Sihhiye, Ankara, Turkey.

Received: 1 May 2018 Accepted: 27 November 2018

Published online: 15 December 2018

\section{References}

1. Barresi R, Campbell KP. Dystroglycan: from biosynthesis to pathogenesis of human disease. J Cell Sci. 2006;119:199-207.

2. Ibraghimov-Beskrovnaya O, Ervasti JM, Leveille CJ, Slaughter CA, Sernett SW, Campbell KP. Primary structure of dystrophin-associated glycoproteins linking dystrophin to the extracellular matrix. Nature. 1992;355:696-702.

3. Cao W, Henry MD, Borrow P, Yamada H, Elder JH, Ravkov EV, Nichol ST, Compans RW, Campbell KP, Oldstone MB. Identification of a-dystroglycan as a receptor for lymphocytic choriomeningitis virus and Lassa fever virus. Science. 1998;282:2079-81.

4. Michele DE, Barresi R, Kanagawa M, Saito F, Cohn RD, Satz JS, Dollar J, Nishino I, Kelley Rl, Somer H, Straub V, Mathews KD, Moore SA, Campbell KP. Post-translational disruption of dystroglycan-ligand interactions in congenital muscular dystrophies. Nature. 2002;418:417-22.

5. Spiropoulou CF, Kunz S, Rollin PE, Campbell KP, Oldstone MB. New World arenavirus clade $\mathrm{C}$, but not clade $\mathrm{A}$ and $\mathrm{B}$ viruses, utilizes alpha-dystroglycan as its major receptor. J Virol. 2002;76:5140-6.

6. Dinçer $P$, Balci B, Yuva Y, Talim B, Brockington M, Dinçel D, Torelli S, Brown S, Kale G, Haliloglu G, Gerçeker FO, Atalay RC, Yakicier C, Longman C, Muntoni $\mathrm{F}$, Topaloglu $\mathrm{H}$. A novel form of recessive limb girdle muscular dystrophy with mental retardation and abnormal expression of alphadystroglycan. Neuromuscul Disord. 2003;13:771-8.

7. Hara Y, Balci-Hayta B, Yoshida-Moriguchi T, Kanagawa M, Beltrán-Valero de Bernabé D, Gündeşli H, Willer T, Satz JS, Crawford RW, Burden SJ, Kunz S, Oldstone MB, Accardi A, Talim B, Muntoni F, Topaloğlu H, Dinçer P, Campbell KP. A dystroglycan mutation associated with limb-girdle muscular dystrophy. N Engl J Med. 2011;364:939-46.

8. Yoshida-Moriguchi T, Campbell KP. Matriglycan: a novel polysaccharide that links dystroglycan to the basement membrane. Glycobiology. 2015; 25:702-13.

9. Godfrey C, Foley AR, Clement E, Muntoni F. Dystroglycanopathies: coming into focus. Curr Opin Genet Dev. 2011;21:278-85.

10. Grewal PK, Hewitt JE. Mutation of Large, which encodes a putative glycosyltransferase, in an animal model of muscular dystrophy. Biochim Biophys Acta. 2002;1573:216-24.

11. Longman C, Brockington M, Torelli S, Jimenez-Mallebrera C, Kennedy C, Khalil N, Feng L, Saran RK, Voit T, Merlini L, Sewry CA, Brown SC, Muntoni F. Mutations in the human LARGE gene cause MDC1D, a novel form of congenital muscular dystrophy with severe mental retardation and abnormal glycosylation of alpha-dystroglycan. Hum Mol Genet. 2003;12:2853-61.

12. van Reeuwijk J, Grewal PK, Salih MA, Beltrán-Valero de Bernabé D, JM ML, Michielse CB, Herrmann R, Hewitt JE, Steinbrecher A, Seidahmed MZ, Shaheed MM, Abomelha A, Brunner HG, van Bokhoven H, Voit T. Intragenic deletion in the LARGE gene causes Walker-Warburg syndrome. Hum Genet. 2007;121:685-90.

13. Grewal PK, Holzfeind PJ, Bittner RE, Hewitt JE. Mutant glycosyltransferase and altered glycosylation of alpha-dystroglycan in the myodystrophy mouse. Nat Genet. 2001;28:151-4.

14. Inamori K, Yoshida-Moriguchi T, Hara Y, Anderson ME, Yu L, Campbell KP. Dystroglycan function requires xylosyl- and glucuronyltransferase activities of LARGE. Science. 2012;335:93-6.

15. Hara Y, Kanagawa M, Kunz S, Yoshida-Moriguchi T, Satz JS, Kobayashi YM, Zhu Z, Burden SJ, Oldstone MB, Campbell KP. Likeacetylglucosaminyltransferase (LARGE)-dependent modification of dystroglycan at Thr-317/319 is required for laminin binding and arenavirus infection. Proc Natl Acad Sci U S A. 2011;108:17426-31.

16. Yoshida-Moriguchi T, Yu L, Stalnaker SH, Davis S, Kunz S, Madson M, Oldstone MB, Schachter H, Wells L, Campbell KP. O-mannosyl 
phosphorylation of alpha-dystroglycan is required for laminin binding Science. 2010;327:88-92.

17. Barresi R, Michele DE, Kanagawa M, Harper HA, Dovico SA, Satz JS, Moore SA, Zhang W, Schachter H, Dumanski JP, Cohn RD, Nishino I, Campbell KP. LARGE can functionally bypass a-dystroglycan glycosylation defects in distinct congenital muscular dystrophies. Nature Med. 2004;10:696-703.

18. Sato S, Omori Y, Katoh K, Kondo M, Kanagawa M, Miyata K, Funabiki K, Koyasu T, Kajimura N, Miyoshi T, Sawai H, Kobayashi K, Tani A, Toda T, Usukura J, Tano Y, Fujikado T, Furukawa T. Pikachurin, a dystroglycan ligand, is essential for photoreceptor ribbon synapse formation. Nature Neurosci. 2008:11:923-31.

19. Willer T, Valero MC, Tanner W, Cruces J, Strahl S. O-mannosyl glycans: from yeast to novel associations with human disease. Cur Opin Struct Biol. 2003;13:621-30.

20. Goddeeris MM, Wu B, Venzke D, Yoshida-Moriguchi T, Saito F, Matsumura K, Moore SA, Campbell KP. LARGE glycans on dystroglycan function as a tunable matrix scaffold to prevent dystrophy. Nature. 2013;503:136-40.

21. Kanagawa M, Nishimoto A, Chiyonobu T, Takeda S, Miyagoe-Suzuki Y, Wang F, Fujikake N, Taniguchi M, Lu Z, Tachikawa M, Nagai Y, Tashiro F, Miyazaki J, Tajima Y, Takeda S, Endo T, Kobayashi K, Campbell KP, Toda T. Residual laminin-binding activity and enhanced dystroglycan glycosylation by LARGE in novel model mice to dystroglycanopathy. Hum Mol Genet. 2009;18:621-31.

22. Vannoy CH, Xu L, Keramaris E, Lu P, Xiao X, Lu QL. Adeno-associated virusmediated overexpression of LARGE rescues a-dystroglycan function in dystrophic mice with mutations in the fukutin-related protein. Hum Gene Ther Method. 2014:25:187-96.

23. Yu M, He Y, Wang K, Zhang P, Zhang S, Hu H. Adeno-associated viralmediated LARGE gene therapy rescues the muscular dystrophic phenotype in mouse models of dystroglycanopathy. Hum Gene Ther. 2013;24:317-30.

24. Ohtsuka Y, Kanagawa M, Yu CC, Ito C, Chiyo T, Kobayashi K, Okada T, Takeda $\mathrm{S}$, Toda $\mathrm{T}$. Fukutin is prerequisite to ameliorate muscular dystrophic phenotype by myofiber-selective LARGE expression. Sci Rep. 2015;5:8316.

25. Jimenez-Mallebrera C, Torelli S, Feng L, Kim J, Godfrey C, Clement E, Mein R Abbs S, Brown SC, Campbell KP, Kröger S, Talim B, Topaloglu H, Quinlivan R, Roper H, Childs AM, Kinali M, Sewry CA, Muntoni F. A comparative study of alpha-dystroglycan glycosylation in dystroglycanopathies suggests that the hypoglycosylation of alpha-dystroglycan does not consistently correlate with clinical severity. Brain Pathol. 2009;19:596-611.

26. Brown SC, Torelli S, Brockington M, Yuva Y, Jimenez C, Feng L, Anderson L, Ugo I, Kroger S, Bushby K, Voit T, Sewry C, Muntoni F. Abnormalities in alpha-dystroglycan expression in MDC1C and LGMD2I muscular dystrophies. Am J Pathol. 2004;164:727-37.

27. Ohlendieck K, Campbell KP. Dystrophin-associated proteins are greatly reduced in skeletal muscle from mdx mice. J Cell Biol. 1991;115:1685-94.

28. Pereira CC, Kiyomoto BH, Cardoso R, Oliveira AS. Duchenne muscular dystrophy: alpha-dystroglycan immunoexpression in skeletal muscle and cognitive performance. Arq Neuropsiquiatr. 2005;63:984-9.

29. Balci-Hayta B, Talim B, Topaloglu H, Kale G, Dincer P. Reduction of LARGE expression in different types of muscular dystrophies other than dystroglycanopathy. Neuromuscul Disord. 2013;23(9-10):p780.

30. Ervasti JM, Burwell AL, Geissler AL. Tissue-specific heterogeneity in alphadystroglycan sialoglycosylation. Skeletal muscle alpha-dystroglycan is a latent receptor for Vicia villosa agglutinin b4 masked by sialic acid modification. J Biol Chem. 1997;272:22315-21.

\section{Ready to submit your research? Choose BMC and benefit from:}

- fast, convenient online submission

- thorough peer review by experienced researchers in your field

- rapid publication on acceptance

- support for research data, including large and complex data types

- gold Open Access which fosters wider collaboration and increased citations

- maximum visibility for your research: over $100 \mathrm{M}$ website views per year

At $\mathrm{BMC}$, research is always in progress.

Learn more biomedcentral.com/submissions 